\title{
ANALISIS UNSUR HARA PUPUK ORGANIK CAIR DARI LIMBAH IKAN MUJAIR (Oreochromis mosambicus) DANAU LINDU DENGAN VARIASI VOLUME MIKRO ORGANISME LOKAL (MOL) BONGGOL PISANG
}

\author{
Nutrient Analysis of Organic Liquid Fertilizer from Waste of Mujair Fish \\ (Oreochromis mosambicus) from Lindu Lake Using Local Microorganism \\ (MOL) of Banana Weevil Variation
}

\author{
*Winda Lepongbulan, Vanny M. A. Tiwow, dan Anang Wahid M. Diah \\ Pendidikan Kimia/FKIP - Universitas Tadulako, Palu - Indonesia 94118 \\ Recieved 07 March 2017, Revised 07 April 2017, Accepted 08 May 2017
}

\begin{abstract}
The Lake Lindu is one of the potential water resources in Central Sulawesi with various species of fish and one of the most commonly found fish is species mujair fish. Mujair fish processing wastes such as offal can be polluted the environment if not managed properly. The study aim is to determine the contents of NPK nutrients in the liquid organic fertilizer by adding MOL banana weevil. The contents of nitrogen $(N)$, phosphorus $(P)$, and potassium $(K)$ was determined by using spectro direct. The NPK contents in the liquid organic fertilizer of mujair fish waste from Lake Lindu reached the maximum NPK contents of nitrogen (N) of $0.311 \%$ by addition $100 \mathrm{~mL}$ MOL banana weevil, phosphorus (P) $0.167 \%$ by addition $150 \mathrm{~mL}$ of MOL banana weevil, and potassium (K) of $0.037 \%$ by addition 150 mL MOL banana weevil.
\end{abstract}

Keywords: organic liquid fertilizer, mujair fish, nitrogen $(\mathrm{N})$, phosphorus $(\mathrm{P})$, potassium $(\mathrm{K})$

\section{Pendahuluan}

Kekayaan ikan di kawasan Indonesia berlimpah dan usaha untuk meningkatkan hasil tangkapannya terus menerus diupayakan. Hasil tangkapan ikan yang berlimpah menjadi ikan sisa atau ikan buangan yang disebabkan oleh berbagai hal misalnya keterbatasan pengetahuan dan sarana para nelayan dalam cara pengolahan ikan. Sisa ikan atau ikanikan yang terbuang tersebut ternyata masih dapat dimanfaatkan (Hapsari \& Welasi, 2013). Limbah baik berupa padatan, cairan, atau gas bila tidak dikelola dan diolah dengan baik akan menimbulkan ketidaknyamanan bagi manusia dan lingkungan, bahkan dapat mencemari dan merusak lingkungan (Indriani, dkk., 2013). Limbah ikan banyak ditemukan di Kota Palu dan salah satu sumber penghasilan ikan di Kota Palu berasal dari danau Lindu. Danau Lindu merupakan salah satu sumber daya perairan yang potensial dikembangkan untuk memenuhi kebutuhan protein dan

*Correspondence:

Winda Lepongbulan

Program Studi Pendidikan Kimia, Fakultas Keguruan dan Ilmu Pendidikan, Universitas Tadulako

email: windalepongbulan20@gmail.com

Published by Universitas Tadulako 2017 meningkatkan pendapatan bagi masyarakat. Danau Lindu kaya akan berbagai jenis ikan seperti mujair, ikan mas, lele, gabus, sidat dan lain-lain (Baedah, 2010).

Secara umum limbah ikan mengandung banyak nutrien yaitu $\mathrm{N}$ (Nitrogen), $\mathrm{P}$ (Phosforus) dan K (Kalium) yang merupakan komponen penyusun pupuk organik (Hapsari \& Welasi, 2013). Pemanfaatan ikan mujair seperti limbah jeroan yang banyak dihasilkan dari kegiatan perikanan memiliki kandungan yang diharapkan dapat meningkatkan unsur hara yang dibutuhkan tanaman dalam pupuk organik cair.

Pupuk buatan yang beredar di pasaran selain harganya mahal juga memiliki dampak buruk bagi lingkungan seperti menurunkan tingkat kesuburan tanah sehingga timbul pemikiran untuk menggunakan pupuk organik. Penggunaan Pupuk Anorganik yang berkepanjangan menyebabkan menurunnya tingkat kesuburan tanah secara signifikan sehingga menurunkan tingkat produktifitas tanaman (Kasim, dkk., 2011). Penggunaan pupuk organik cair dapat meningkatkan kesuburan tanah yang dirusak oleh penggunaan 
pupuk anorganik. Pupuk organik cair berfungsi meningkatkan pertumbuhan tanaman (Ganefati, dkk., 2014).

Pupuk organik merupakan pupuk yang terbuat dari bahan alam dan memiliki ciri kandungan haranya banyak tetapi dalam jumlah sedikit. Penggunaan pupuk organik pada tanaman tidak hanya memberikan unsurunsur yang dibutuhkan tanaman, tetapi juga dapat memperbaiki struktur tanah. Pupuk organik memiliki dua jenis yaitu pupuk organik cair dan pupuk organik padat (Mazaya, dkk., 2013).

Proses pembuatan pupuk organik cair berlangsung secara anaerob (dalam kondisi tidak membutuhkan oksigen) atau secara fermentasi tanpa bantuan sinar matahari. Pupuk organik merupakan pupuk yang terbuat dari bahan organik. Sumber bahan baku organik ini dapat diperoleh dari berbagai limbah. Biasanya untuk membuat pupuk organik ini ditambahkan larutan mikroorganisme untuk mempercepat pendegradasian (Prihandarini, 2014).

Pupuk organik berperan dalam memperbaiki sifat fisik, kimia, dan biologi tanah. Pemanfaatan limbah ikan juga mengurangi pencemaran lingkungan yang diakibatkan limbah hasil pengolahan ikan yang dibuang begitu saja tanpa memperhatikan dampak negatifnya terhadap lingkungan. Pemanfaatan limbah ikan menjadi pupuk organik bertujuan untuk menghasilkan pupuk yang kaya berbagai nutrien yang diperlukan tanaman, mengatasi kelangkaan pupuk, dan mendukung program pemerintah yaitu "Go Organic' (Hapsari \& Welasi, 2013).

MOL bonggol pisang adalah mikroorganisme lokal yang dibuat dari bonggol pisang sebagai penambah nutrisi unsur hara tanaman dan digunakan sebagai biovaktor untuk mempercepat fermentasi. Tulisan ini dimaksudkan untuk mendeskripsikan kondisi optimum pembuatan pupuk organik cair dari limbah ikan mujair dengan membandingkan pupuk yang ditambahkan oleh mikroorganisme lokal yaitu MOL bonggol pisang dengan yang tidak ditambahkan dan untuk menentukan kandungan unsur hara NPK pada pupuk organik cair dari limbah ikan Mujair yang berasal dari danau Lindu.

\section{Metode}

\section{Alat dan Bahan}

Alat yang digunakan pada penelitian ini meliputi: wadah sampel, gelas kimia, erlenmeyer, kertas saring, corong, gelas ukur, spatula, labu ukur, neraca digital, spectro direct (RS232 Serial No. 1257060900344), dan labu kjeldahl .

Bahan yang digunakan pada penelitian ini meliputi: limbah jeroan ikan mujair, gula pasir, gula merah, aquadest, air bekas cucian beras (cucian pertama), bongol pisang, tablet phosphate 1 dan 2, tablet kalium, larutan $\mathrm{H}_{2} \mathrm{SO}_{4}$ (Merck), tablet kjeldahl.

\section{Prosedur penelitian}

Pembuatan Mikroorganisme Lokal (MOL) Bonggol Pisang

MOL bonggol pisang dibuat dari bonggol pisang kepok (Musa acuminata balbisiana). Sebanyak $1 \mathrm{~kg}$ bonggol pisang yang telah dihaluskan dimasukkan ke dalam wadah dan ditambahkan dengan air cucian beras sebanyak 2 liter dan gula merah sebanyak $1 / 5 \mathrm{~kg}$. Kemudian ditutup rapat hingga tidak ada udara yang bisa masuk dan selanjutnya difermentasi selama 7 hari (Faridah, dkk., 2014).

\section{Pembuatan Molase}

Cairan molase dibuat dengan menambahkan $1 \mathrm{~kg}$ gula pasir ke dalam $1000 \mathrm{~mL}$ aquadest (perbandingan 1:1). Cairan molase ini berguna sebagai sumber energi dan penyubur bakteri.

\section{Pembuatan Pupuk Organik Cair}

Masing-masing sebanyak 200 gram limbah jeroan ikan Mujair dimasukkan ke dalam empat wadah tertutup. Selanjutnya ditambahkan sebanyak $100 \mathrm{~mL}$ cairan molase, dan 1 liter aquades. Masing-masing wadah ditambahkan dengan MOL bonggol pisang dengan volume yang berbeda-beda pada setiap wadah, yaitu $0 \mathrm{~mL}, 50 \mathrm{~mL}, 100 \mathrm{~mL}$ dan 150 $\mathrm{mL}$ MOL bonggol pisang. Selanjutnya wadah ditutup rapat hingga udara tidak bisa masuk dan kemudian di fermentasi selama 14 hari (Waryanti, dkk., 2013).

\section{Analisis Sampel}

Pengujian sampel meliputi pengujian kadar NPK yang dilakukan di Laboratorium Kimia Fakultas Keguruan dan Ilmu Pendidikan Universitas Tadulako, meliputi:

\section{Kadar Nitrogen (N)}

Sampel hasil fermentasi diambil sebanyak $10 \mathrm{~mL}$ dimasukkan ke dalam labu Kjeldahl, kemudian ditambahkan dengan $10 \mathrm{~mL} \mathrm{H}_{2} \mathrm{SO}_{4}$ pekat dan satu sendok spatula tablet Kjeldahl. Selanjutnya didestruksi (dipanaskan) sampai mendidih dan larutan menjadi jernih. Setelah 
didestruksi larutan dibiarkan beberapa saat sampai dingin. Selanjutnya larutan jernih yang telah didestruksi diencerkan sampai volume $100 \mathrm{~mL}$. Sampel yang telah diencerkan kemudian diambil masing-masing sebanyak $10 \mathrm{~mL}$ dan dimasukkan ke dalam 3 buah vial (tempat sampel berukuran $10 \mathrm{~mL}$ yang bentuknya menyerupai botol) untuk dianalisis menggunakan alat spectro direct (Warsito, 2016)

\section{Kadar Phosforus (P)}

Sampel pupuk organik cair disaring sehingga menghasilkan filtrat. Kemudian sebanyak $2 \mathrm{~mL}$ filtrat diencerkan dengan aquadest dalam labu ukur $30 \mathrm{~mL}$ sampai tanda batas. Larutan yang telah siap dianalisis dimasukkan ke dalam vial. Analisis kadar P pada sampel pupuk organik cair dari limbah ikan mujair dilakukan dengan memasukkan masing-masing $10 \mathrm{~mL}$ sampel ke dalam vial dan ditambahkan reagen $\mathrm{P}$ (tablet phosphate 1 dan 2) ke dalam masing-masing vial tersebut. Kemudian ketiga vial tersebut dikocok sampai pereaksi larut semua menjadi homogen. Selanjutnya diukur kadar P dengan menggunakan spectro direct.

\section{Kadar Kalium (K)}

Pupuk organik cair disaring dan filtrat hasil penyaringan diambil sebanyak $2 \mathrm{~mL}$. Kemudian filtrat diencerkan dengan aquadest dalam labu ukur $10 \mathrm{~mL}$ sampai tanda batas. Larutan yang telah siap dianalisis dimasukkan ke dalam vial. Analisis kadar K pada sampel pupuk organik cair dari limbah ikan mujair dilakukan dengan memasukkan masing-masing $10 \mathrm{~mL}$ sampel ke dalam 3 buah vial dan ditambahkan reagen $\mathrm{K}$ (tablet Kalium) ke dalam masing-masing vial tersebut. Kemudian ketiga vial tersebut dikocok sampai pereaksi larut semua menjadi homogen. Selanjutnya kadar K diukur dengan menggunakan spectro direct.

\section{Hasil dan Pembahasan}

Pembuatan Pupuk Organik Cair

MOL bonggol pisang adalah mikroorganisme lokal yang dibuat dari bonggol pisang. Bonggol pisang memiliki banyak mata tunas yang didalamnya terdapat banyak giberelin dan sitokinin sehingga dapat mengundang mikroorganisme lain untuk datang. Bonggol pisang mengandung beberapa mikroorganisme yang berperan baik dalam penyuburan tanah (Faridah, dkk., 2014). Jenis mikroba yang telah diidentifikasi pada MOL bonggol pisang antara lain Bacillus sp, Aeromonassp, Aspergillus nigger.
Mikroba inilah yang akan mengurai bahan organik. Mikroba pada MOL bonggol pisang akan bertindak sebagai dekomposer bahan organik yang akan dikomposkan (Ole, 2013).

MOL bonggol pisang dibuat dengan cara menghaluskan $1 \mathrm{~kg}$ bonggol pisang kepok kemudian ditambahkan dengan $2 \mathrm{~L}$ air cucian beras dan $200 \mathrm{~g}$ gula merah yang terlebih dahulu dihaluskan. Hasil campuran tersebut kemudian difermentasi selama 7 hari. Air cucian beras dan gula berfungsi sebagai sumber energi dan penyubur bakteri. Molase mengandung nutrisi cukup tinggi untuk kebutuhan mikroorganisme, sehingga dapat dijadikan bahan alternatif untuk sumber energi dalam media fermentasi. MOL yang telah difermentasi selama 7 hari ini dapat digunakan langsung sebagai pupuk cair penambah nutrisi unsur hara tanaman atau bisa digunakan sebagai biovaktor untuk mempercepat fermentasi. Pada proses fermentasi penggunaan MOL akan dihasilkan alkohol yang ditandai aroma alkohol setelah fermentasi selama 7 hari. Proses fermentasi pembuatan MOL dihasilkan alkohol dengan reaksi sebagai berikut (Indriani, dkk., 2013):

$$
\mathrm{C}_{6} \mathrm{H}_{12} \mathrm{O}_{6} \longrightarrow 2 \mathrm{C}_{2} \mathrm{H}_{5} \mathrm{OH}+2 \mathrm{CO}_{2}+2 \mathrm{NADH}_{2}+\text { Energi }
$$

Proses fermentasi merupakan proses biokimia dimana terjadi perubahan-perubahan atau reaksi-reaksi kimia dengan pertolongan jasad renik penyebab fermentasi tersebut bersentuhan dengan zat makanan yang sesuai dengan pertumbuhannya. Akibat terjadinya fermentasi sebagian atau seluruhnya akan berubah menjadi alkohol setelah beberapa waktu lamanya (Endah, dkk., 2007).

Berikut reaksi yang terjadi pada proses anaerobik saat pembuatan pupuk organik cair (Sundari, dkk., 2014) :

Bahan Organik $\stackrel{\text { Mikroorganisme }}{\longrightarrow} \mathrm{CH}_{4}+\mathrm{Hara}+$ Humus

Kondisi optimum pada pembuatan pupuk organik cair dari limbah ikan mujair yang berasal dari danau Lindu yaitu pada pupuk yang ditambahkan dengan mikroorganisme lokal (MOL) bonggol pisang karena memiliki NPK yang lebih tinggi dibandingkan dengan pupuk yang tidak ditambahkan dengan MOL bonggol pisang. Mikroorganisme lokal (MOL) adalah mikroorganisme yang terbuat dari bahanbahan alami sebagai medium berkembangnya mikroorganisme yang berguna untuk mempercepat penghancuran bahan organik (proses dekomposisi menjadi kompos/pupuk organik). Disamping itu juga dapat berfungsi sebagai tambahan nutrisi bagi tanaman, yang 
dikembangkan dari mikroorganisme tersebut. Semakin banyak mikroorganisme pada bahan, proses dekomposisi bahan organik atau pengomposan semakin cepat (Panudju, 2011).

\section{Kadar Nitrogen}

Berdasarkan studi yang telah dilakukan, dapat diketahui kadar nitrogen dari pupuk organik cair dari limbah ikan mujair yang berasal dari danau Lindu. Tabel 1 menunjukkan kadar nitrogen yang diperoleh pada pupuk organik cair dari limbah ikan mujair.

Tabel 1. Kadar Unsur Harpada Pupuk

Organik Cair dari Limbah Ikan Mujair

\begin{tabular}{|c|c|c|c|}
\hline Sampel & $\% \mathrm{~N}$ & $\% \mathrm{P}$ & $\% \mathrm{~K}$ \\
\hline $\begin{array}{c}\text { A (0 } \mathrm{mL} \mathrm{Mol} \mathrm{bonggol} \\
\text { pisang) }\end{array}$ & $0,194 \%$ & $0,131 \%$ & $0,030 \%$ \\
\hline $\begin{array}{l}\mathrm{B}(50 \mathrm{~mL} \mathrm{Mol} \mathrm{bonggol} \\
\text { pisang) }\end{array}$ & $0,304 \%$ & $0,149 \%$ & $0,035 \%$ \\
\hline $\begin{array}{c}\mathrm{C}(100 \mathrm{~mL} \text { mol bonggol } \\
\text { pisang })\end{array}$ & $0,311 \%$ & $0,154 \%$ & $0,036 \%$ \\
\hline $\begin{array}{c}\mathrm{D} \text { (150 } \mathrm{mL} \text { mol bonggol } \\
\text { pisang) }\end{array}$ & $0,253 \%$ & $0,167 \%$ & 0,037 \\
\hline
\end{tabular}

Penentuan kadar nitrogen pada sampel pupuk organik dari limbah ikan mujair dilakukan dengan menggunakan metode Kjeldahl. Prosedur Kjeldahl memiliki tiga tahap yaitu penghancuran (destruksi), netralisasi atau distilasi, dan yang terakhir yaitu titrasi. Studi ini hanya dilakukan tahap destruksi saja, hal ini karena penentuan nitrogen totalnya dilakukan dengan menggunakan alat spectro direct.

Analisis secara kuantitatif dengan spectrofotometer harus menggunakan larutan berwarna dan bening agar kadar nitrogen dapat diketahui. Sampel yang berupa larutan berwarna dan keruh harus didestruksi dahulu agar didapatkan larutan yang siap untuk dianalisis. Destruksi yang digunakan disini adalah destruksi basah. Destruksi basah merupakan proses perombakan oksidatif sampel organik menggunakan asam pengoksidasi seperti asam nitrat, asam perkolat, asam sulfat atau campuran asam-asam tersebut. Kandungan ion-ion dalam sampel dapat mengganggu proses analisis metode spectrofotometer. Proses destruksi dapat menghilangkan kandungan ion lain sehingga kesalahan dalam pembacaan saat analisis ditekan seminimal mungkin. Perombakan organologam menjadi bentuk anorganik yang siap dianalisis terjadi pada proses ini. Destruksi dikatakan berhasil apabila didapatkan larutan akhir yang jernih (Mazaya, dkk., 2013).

Metode Kjeldahl pada tahap destruksi dilakukan dengan cara sampel yang akan dihancurkan (destruksi) secara sempurna sehingga seluruh karbon dan oksigen teroksidasi dan nitrogen diubah menjadi amonium sulfat. Proses penghancuran ini dilakukan dengan menambahkan asam kuat pekat (asam sulfat) dan tablet Kjeldahl ke dalam sampel dan proses pemanasan padasuhu tinggi, sehingga dihasilkan larutan berwarna jernih yang mengandung amonium sulfat (Andarwulan, dkk., 2011).

Sampel yang tidak ditambahkan dengan MOL bonggol pisang memiliki kadar nitrogen yang paling kecil yaitu 0,194\% dibanding dengan sampel yang ditambahkan dengan MOL bonggol pisang. Kandungan nitrogen yang paling tinggi yaitu $0,311 \%$ yang terdapat pada sampel dengan penambahan MOL sebanyak $100 \mathrm{~mL}$, hal ini menandakan bahwa penambahan MOL bonggol pisang paling optimal. Perbedaan kadar nitrogen dari masingmasing sampel dikarenakan pemberian berbagai sumber dekomposeryang berbeda menyebabkan perbedaan kadar nitrogen (Rusvita, 2012). Salah satu kandungan gizi dalam bonggol pisang yaitu protein. Adanya penambahan MOL bonggol pisang maka akan meningkatkan kadar nitrogen dari pupuk organik tersebut.

\section{Kadar Phosforus (P)}

Kadar phosforus yang diperoleh pada studi analisis kadar unsur hara pada pupuk organik cair dari limbah ikan mujair yang berasal dari danau Lindu ditunjukkan pada Tabel 1. Penentuan kadar phosforus pada pupuk organik cair dari limbah ikan mujair dilakukan dengan menggunakan spectro direct. Pengukuran konsentrasi logam dengan menggunakan spectro direct haruslah berupa larutan yang berwarna. Oleh karena itu sampel pupuk organik cair dari limbah ikan mujair disaring dan dikomplekskan dengan reagen (pereaksi) yaitu tablet phospate 1 dan 2. Reagent yang digunakan harus betul-betul spesifik hanya bereaksi dengan analit yang akan dianalisis. Selain itu juga produk senyawa berwarna yang dihasilkan harus stabil untuk jangka waktu lama (Sastrohamidjojo, 2007).

Kandungan phosforus paling tinggi pada studi ini yaitu $0,167 \%$ terdapat pada penambahan MOL bonggol pisang dengan volume $150 \mathrm{~mL}$. Penambahan volume MOL bonggol pisang menaikkan kadar phosforus. Hal ini karena kandungan phosforus dalam bonggol pisang kedua tertinggi setelah air sehingga dengan pengurangan volume MOL bonggol pisang maka akan menurunkan kandungan phosforus (Ole, 2013).

Kandungan mineral pada ikan tergantung pada spesies, jenis kelamin, siklus biologis, dan bagian tubuh ikan yang dianalisis. Kandungan mineral ikan juga tergantung pada faktor ekologis seperti musim, tempat pengembangan 
jumlah nutrisi yang tersedia, suhu dan salinitas air. Mineral utama yang diperlukan adalah kalsium dan phosforus. Kalsium dapat dijumpai pada air-air berkesadahan tinggi sedangkan phosforus dapat dijumpai pada tanaman air. Di dalam ekosistem air terjadi daur phosforus. Fosfat yang terlarut di dalam air diserap oleh ganggang dan tumbuhan air, sedangkan ikan-ikan mendapatkan fosfat melalui rantai makanan (Ye, dkk., 2006) .

\section{Kadar Kalium (K)}

Sampel pupuk organik cair dari limbah ikan mujair yang telah disaring dikomplekskan dengan reagen yaitu tablet kalium. Kadar kalium yang diperoleh ditunjukkan pada Tabel 1. Kandungan kalium yang paling rendah yaitu $0,030 \%$ terdapat pada sampel yang tidak ditambahkan dengan MOL bonggol pisang dan yang paling tinggi yaitu $0,037 \%$ terdapat pada sampel yang ditambahkan MOL bonggol pisang dengan volume $150 \mathrm{~mL}$. Adanya perbedaan kadar kalium dari setiap sampel karena adanya perbedaan komposisi bahan yang dicampurkan sehingga mempengaruhi kandungan nutrisi organik di dalamnya (Dwicaksono, dkk., 2015).

Peranan utama nitrogen $(\mathrm{N})$ bagi tanaman adalah untuk merangsang pertumbuhan secara keseluruhan, khususnya batang, cabang, dan daun. Selain itu, nitrogen pun berperan dalam pembentukan hijau daun yang sangat berguna dalam proses fotosintesis. Fungsi lainnya ialah membentuk protein, lemak, dan berbagai persenyawaan organik lainnya. Unsur phosforus (P) bagi tanaman berguna untuk merangsang pertumbuhan akar, khususnya akar benih dan tanaman muda. Selain itu, phosforus berfungsi sebagai bahan mentah untuk pembentukan sejumlah protein tertentu, membantu asimilasi dan pernapasan, serta mempercepat pembungaan, pemasakan biji, dan buah. Fungsi utama kalium pun berperan dalam memperkuat tubuh tanaman agar daun bunga, dan buah tidak mudah gugur (Lingga \& Marsono, 2008).

\section{Kesimpulan}

Hasil analisis kadar unsur hara NPK pada pupuk organik cair dari limbah ikan mujair yang berasal dari danau Lindu yaitu dengan nilai maksimum terhadap variasi volume MOL bonggol pisang dalam penelitian ini yaitu untuk nitrogen $(\mathrm{N})$ sebesar $0,311 \%$ pada penambahan $100 \mathrm{~mL}$ MOL bonggol pisang, phosfor $0,167 \%$ pada penambahan $150 \mathrm{~mL}$ MOL bonggol pisang, dan kalium 0,037\% pada penambahan $150 \mathrm{~mL}$ MOL bonggol pisang.

\section{Ucapan Terima Kasih}

Ucapan terimakasih penulis sampaikan kepada Paulus Hengky Abram dan Tasrik yang telah memberikan bimbingan dan masukan dalam menyelesaikan penelitian ini.

\section{Referensi}

Andarwulan, N., Kusnandar, F. \& Herawati, D. (2011). Analisis pangan. Jakarta: Dian Rakyat.

Baedah, M. A. (2010). Mengelola danau lindu secara bijak. Sulawesi Tengah: Dinas Kelautan dan Perikan.

Dwicaksono, R. B.D., Suharto, B. \& Susanawati, L. D. (2015). Pengaruh penambahan effective microorganism pada limbah cair industri perikanan terhadap kualitas pupuk organik cair. Jurnal Sumberdaya Alam dan Lingkungan, 1(1), 7-11.

Endah, R. D., Sperisa, D., Nur, A. \& Paryanto. (2007). Pengaruh kondisi fermentasi terhadap yield etanol pada pembuatan bioetanol dari pati garut. Jurnal Gema Teknik, 10(2), 83-88.

Faridah, A., Sumiyati, S. \& Handayani, D. S. (2014). Studi perbandingan pengaruh penambahan aktivator agri simba dengan mol bonggol pisang terhadap kandungan unsur hara makro (CNPK) kompos dari blotong (sugarcane filter cake) dengan variasi penambahan kulit kopi. Jurnal Teknik Lingkungan, 3(1), 1-9.

Ganefati, S. P., Sutomo, A. H. \& Iswanto. (2014). Urinoir model as liquid organic fertilizer producer of nitrogen $(\mathrm{N})$, phospate $(\mathrm{P})$, and potassium $(\mathrm{K})$. International Journal of Public Health Science, 3(1), 23-28.

Hapsari, N. \& Welasi, T. (2013). Pemanfaatan limbah ikan menjadi pupuk organik. Jurnal Teknik Lingkungan, 2(1), 1-6.

Indriani, F., Sutrisno, E. \& Sumiyati, S. (2013). Studi pengaruh penambahan limbah ikan pada proses pembuatan pupuk cair dari urin sapi terhadap kandungan unsur hara makro (CNPK) Jurnal Teknik Lingkungan, 2(2), 1-16.

Kasim, S., Ahmed, O. H. \& Majid, N. M. A. (2011). Effectiveness of liquid organicnitrogen fertilizer in enhancing nutrients 
uptake and use efficiency in corn (zea mays). African Journal of Biotechnology, 10(12), 2274-2281.

Lingga, P. \& Marsono. (2008). Petunjuk penggunaan pupuk. Jakarta: Penebar Swadaya.

Mazaya, M., Susatyo, E. B. \& Prasetya, A. T. (2013). Pemanfaatan tulan ikan kakap untuk meningkatkan kadar fosfor pupuk cair limbah tempe. Indonesian Journal of Chemical Science, 2(1), 7-11.

Ole, M. B. B. (2013). Penggunaan mikroorganisme bonggol pisang (musa paradisiciaca) sebagai dekomposer sampah organik. Skripsi mahasiswa sarjana pada Program Studi Biologi Universitas Atma Jaya Yogyakarta. Retrieved from e-journal. uajy.ac.id/3963/3/2BL01047.pdf

Panudju, T. I. (2011). Pedoman teknis pengembangan rumah kompos tahun anggaran 2011. Jakarta: Direktorat Perluasan dan Pengelolaan Lahan, Direktorat Jendral Prasarana dan Sarana Pertanian Kementrian Pertanian.

Prihandarini, R. (2014). Manajemen sampah, daur ulang sampah menjadi pupuk organik. Jakarta: Penerbit PerPod.

Rusvita, L. (2012). Kualitas kompos tandan kosong kelapa sawit dengan pemberian berbagai sumber dekomposer berbeda pada konsentrasi yang berbeda. Skripsi mahasiswa pada Program Studi Agroteknologi Fakultas Pertanian dan Peternakan Universitas Islam Negeri Sultan Syarif Kasim Riau Pekanbaru. Retrieved from repository.win-suska. ac.id/5262-1-2012 201286PTN.pdf

Sastrohamidjojo, H. (2007). Spektroskopi. Yogyakarta: Liberty Yogyakarta.

Sundari, I., Maruf, W. F. \& Dewi, E. N. (2014). Pengaruh penggunaan bioaktivator EM4 dan penambahan tepung ikan terhadap spesifikasi pupuk organik cair rumput laut gracilaria sp. Jurnal Pengolahan dan Bioteknologi Hasil Perikanan, 3(3), 88-94.

Warsito, J. (2016). Pemanfaatan limbah tandan kosong kelapa sawit sebagai bahan pembuatan pupuk organik. Skripsi sarjana pada Program Studi Pendidikan Kimia Universitas Tadulako Palu., Tidak diterbitkan.

Waryanti, A., Sudarno \& Sutrisno, E. (2013). Studi pengaruh penambahan sabut kelapa pada pembuatan pupuk cair dari limbah cucian ikan terhadap kualitas unsur hara makro (CNPK). Jurnal Teknik Lingkungan, 2(2), 1-7.

Ye, C. X., Liu, Y. J., Tian, L. X., Mai, K. S., Du, Z. Y., Yang, H. J. \& Niu, J. (2006). Effect of dietary calcium and phosphorus on growth, feed efficiency, mineral content and body composition of juvenil grouper, epinephelus coioides. Aquaculture, 255(1-4), 263-271. 